\title{
THE RESEARCH OF THE EMOTIONAL PROFILE OF ATTACHMENT
}

УДК 159.9.072.43

DOI https://doi.org/10.32843/2663-

5208.2021.21.27

\section{Мазяр О.В.}

к.психол.н., доцент,

доцент кафредри соціальної

та практичної психології

Житомирський державний університет

імені Івана Франка

Недзельська л.в.

аспірантка кафедри соціальної

та практичної психології

Житомирський державний університет

імені Івана Франка
Вирішення проблеми прив'язаності має неабияке практичне значення у зв'язку 3 тим, що прив'язаність часто стає предметом звернення клієнтів за психологічною допомогою в межах консультаційної та психокорекційної роботи. Водночас ї̈ теоретична розробленість лишається на рівні систематизованих спостережень за стосунками батьків та дітей і не дозволяє здійснювати психологічну діагностику прив'язаності під кутом зору емочійної амбівалентності. Емоційна амбівалентність закономірно загострюється у підлітковому віці, що зумовлюється кризою стосунків $і$ транссрормацією системи прив'язаності. Стаття має завданням, по-перше, показати методологію дослідження емоційного аспекту прив'язаності підлітка, по-друге, обгрунтувати припущення про те, що прив'язаність, як будь-який психологічний френомен, $\epsilon$ структурно складним френоменом. Ідеограсрічне дослідження здійснюється з використанням методу фракторного аналізу та оцінки кореляції емоційних реакцій суб'єкта. Аналіз результатів дослідження показує, що у конкретному випадку підліток, який відчуває прив'язаність до певних осіб (виокремлено 12 об'єктів прив'язаності), демонструє значний спектр емоційних реакцій на них. Встановлена плеяда емоційних реакцій не $є$ однозначною: суб'єкт виявляє не тільки так звані позитивні емоції (інтерес, подив, радість), але й емоції негативного штибу (страх, огида, сором, смуток, презирство). Два з трьох виділених фрактори виявляються біполярними. Найбільший фактор засвідчує прагнення суб'єкта сепаруватися у стосунках з особами, до яких відчуває прив'язаність. Особливо це очевидно в емоційному ставленні до батьків. Дослідження дозволило сорормулювати гіпотези щодо емоційних аспектів психологічної проблеми підлітка, іденти фрікувати точки його амбівалентності, які можуть стати предметом звернення за психологічною допомогою.
Ключові слова: прив'язаність, емоція, амбівалентність, психічна суперечність, фракторний аналіз

Solving the attachment issues has great practical importance due to the fact that, that attachment is often the subject of seeking help to the psychologist within the framework of counseling and psycho-correctional work. At the same time, its theoretical development remains at the level of systematic observations of the relationship between parents and children and does not allow to carry out psychological diagnostics of attachment in terms of emotional ambivalence. Emotional ambivalence naturally escalates in adolescence due to relationship crisis and attachment system transformation. The article aims are, firstly, to show the methodology of studying the emotional aspect of attachment in adolescence, and secondly, to substantiate the assumption that attachment as any psychological phenomenon is a structurally complex phenomenon. Ideographic research is carried out using the method of factor analysis and evaluation of the correlation of emotional reactions of the subject. Analysis of the results of the study shows that in a particular case, a teenager who feels attached to certain people (12 objects of attachment are identified), demonstrates a significant range of emotional reactions to them. The created set of emotional reactions is not unambiguous: the subject shows not only the so-called positive emotions (interest, surprise, joy), but also negative emotions (fear, disgust, shame, sadness, contempt). Two of the three selected factors are bipolar. The biggest factor indicates the desire of the subject to separate in relations with persons to whom he feels attached. This is especially evident in the emotional attitude towards parents. The study allowed us to formulate hypotheses about the emotional aspects of the psychological problem of adolescents, to identify the points of his ambivalence, which may be the subject of seeking for psychological help.

Key words: attachment, emotion, ambivalence, mental contradiction, factor analysis.
Постановка проблеми. Кінцева мета соціалізації - сепарація від батьків. Зрозуміло, що досягнення психологічної зрілості передбачає здійснення такої сепарації, яка не розриває значущі соціальні контакти, а трансформує ї, що дозволяє суб'єкту набути достатнього рівня самостійності у соціальному функціонуванні. Але що означає ця трансформація в емоційному аспекті? Зникнення одних почуттів і появу інших? Відповіді на ці питання можуть бути отримані лише за умови аналізу в межах теорії, спрямованої на пояснення генезису і динаміки психічної суперечності.

Однією з дотичних проблем є загальна теорія прив'язаності, яка покликана пояснити природу базових стосунків. Це передбачає здатність дослідників у психологічному ана- лізі феномену прив'язаності піднятися вище міркувань щодо ролі та місця материнського інстинкту і дитячого імпринтингу у процесі соціалізації.

Аналіз останніх досліджень і публікацій. Феномен прив'язаності здебільшого аналізується у площині стосунків батьків і дітей. Прив'язаність стає запорукою виживання дитини, позаяк сприяє тому, що дитина перебуватиме біля матері (родини) достатню кількість часу, щоби соціалізуватися й отримати об'єктивні підстави бути самостійною. У протилежному разі отримуємо відповідні розлади прив'язаності [8]. Власне, прив'язаність стає підґрунтям для становлення базової форми та змісту взаємостосунків, що переконливо обґрунтовано ще К. Хорні [6]. 
Розрив із родиною повинен відбутися таким чином, щоби суб'єкт не дискредитував, а екстраполював прив'язаність на інших осіб, зокрема на членів нової родини [10]. Саме цей перехід, який потрапляє на підлітковий та юнацький вік, становить один із найбільш кульмінаційних моментів психічного розвитку людини. Не дарма О.М. Леонтьєв називає його «другим народженням особистості» [2], позаяк відбувається трансформація несвідомої прив'язаності суб'єкта до батьківської родини у більш свідому їі форму, яка позначається на функціональній ефективності індивіда у змінених соціальних умовах $[7 ; 9]$.

Крім того, слабко розкритою лишається проблема змістовної наповненості феномену прив'язаності. Прив'язаність трактується здебільшого як динамічний емоційний зв'язок між певними особами, що зумовлює їхню тісну взаємодію, емоційну взаємозалежність. Але у чому суть цього зв'язку з формального та змістовного погляду? Які емоції складають динаміку прив'язаності? Як назагал здійснювати дослідження прив'язаності, якщо не брати до уваги системне спостереження? Відповіді на ці питання далекі від остаточного формулювання, відтак $€$ актуальними у розвитку психологічної науки.

Постановка завдання. Мета статті в межахідеографічного підходупродемонструвати методологію дослідження емоційного профілю прив'язаності й підтвердити припущення про структурну складність феномену.

Виклад основного матеріалу дослідження. Теоретико-методологічною основою дослідження є максима: психічна суперечність $\epsilon$ базовою умовою розвитку особистості [4]. Ця суперечність представлена на рівні антитетичних сигнальних систем (першої та другої), генетичного та соціального чинників розвитку, темпераментального та характерологічного чинників поведінки тощо. Психічна адекватність суб'єкта визначається здатністю зберігати баланс психічної суперечності, сягати компромісів між задоволенням біологічних потреб і соціальних вимог, що лишає простір для унікальної траєкторії ефективної функціональності. На елементарному рівні це представлено бінарною структурою одиниць психічного аналізу: емоції, смислу, поведінкового акту (комунікації). Причому одна частина бінарного нервово-психічного утворення підлягає усвідомленню і може вважатися домінантною, інша - несвідома і певний час зостається субдомінантною. На прикладі емоційного аналізу особистісної проблеми нами показувалося, що домінантна частина артикулюється суб'єктом (що робить можливим дослідження за допомогою стандартизованих опитувальників), але, втім, неповна, оскільки неусвідомлено доповнюється іншими (субдомінантними) реакціями [3].
Базова психічна суперечність є наслідком того, що й на елементарному рівні психіка людини суперечна. Кожна елементарна нервово-психічна реакція становить суперечність. Цей фізіологічний факт усвідомлюється суб'єктом дискретно, на рівні амбівалентних почуттів чи когнітивного абсурду, що становить предмет звернення за психологічною допомогою. Це означає, що проблема прив'язаності повинна трактуватися з такої ж позиції: любов до об'єкта неодмінно «супроводжується» іншими емоційними реакціями, в тому числі нервово-психічними. Здатність диференціювати прив'язаність як винятково любов у цьому разі $є$ помилковою. Індивідуальні відмінності у прив'язаності визначаються цим «додатковим» емоційним нашаруванням. Власне, саме це робить дослідження за допомогою опитувальників неповним і, як наслідок, неточним. Опитувальники здатні встановити, так би мовити, усвідомлювану частину емоції, рівень інтенсивності її прояву, але несвідома частина залишається незауваженою, хоча саме вона унікально «забарвлює» досліджуваний феномен, показує його зв'язок з елементами набутого досвіду.

Вказана особливість діагностики може бути виконана тільки за умови вербалізації всього спектру емоційного реагування, що очевидно суперечить психічній реальності: суб'єкт не здатен вербалізувати неусвідомлювані аспекти досвіду. Психологічна діагностика виявляється затиснутою між методологіями: опитувальники не здатні виявити несвідомий аспект психічного життя, а проєктивні методи, дарма що спрямовані вказувати на зміст несвідомого, вельми сумнівні у власних інтерпретаціях. Таким чином, дослідники лишаються в межах украй імовірнісних припущень щодо точності діагностики того чи іншого феномену.

Складність дослідження зумовлена ще й тією обставиною, що емоцію не можна розглядати як звичайну суму нервово-психічних реакцій. Інтегрований результат емоції - збуджені та загальмовані нервово-психічні реакції. Це показано нами на прикладі процесу парабіозу, коли зіткнення двох центрів збудження призводить до того, що один із них набуває робочого ефекту, а інший - загальмовується, але не зникає. Останній продовжує функціонувати несвідомо і тільки «чекає» релевантної ситуації, щоби актуалізуватися й загальмувати «партнерську» реакцію. Адже спільно перебувати у збудженому стані вони не можуть [5]. Вони тяжіють до того, щоби бути колись одночасно загальмованими (правильно витісненими). Власне, у цій інверсії криється суть психодинаміки людини.

Такий підхід ставить під сумнів академічну теорію емоцій, бо заперечує існування так званих чистих емоцій. Питання не в тому, 
щоб робити поправки на обов'язкові нашарування, а щоби вважати ці нашарування ситуаційно субдомінантними. Зміна емоції $€$ не запереченням попередньої емоції, повним гальмуванням, а здебільшого є їі природною трансформацією, коли одна емоція має у собі частку інших, причому щоразу цей вміст може різнитися. Коли говоримо, що «від кохання до ненависті один крок», то слід розуміти, що у конкретному випадку ніяка любов без ненависті не існувала, вона тільки не усвідомлювалася суб'єктом у такому нерозривному зв'язку. Відповідно, розкриття проблеми прив'язаності вимагає встановлення подібних зв'язків. Назагал така робота вперше презентована психоаналізом, але не залишає певності, що надані інтерпретації є об'єктивними та не криють проєкції інтерпретатора.

Наше дослідження спрямоване на виявлення емоційного складу такого феномену, як прив'язаність. 3 цією метою ми просимо респондентів: 1) визначити коло осіб, до яких відчувають прив'язаність (не менше $10)$, 2) виявити до них власне емоційне ставлення за вказаним реєстром [1]. Результати такого дослідження піддаються процедурі факторизації. Зауважимо, що ми не ставимо завданням з'ясувати універсальний набір емоцій, який наповнює досліджуваний феномен, а лише показуємо шлях до дослідження прив'язаності як такої. Така процедура може бути покладена в основу психотерапевтичного процесу, оскільки дозволить фахівцю з'ясувати основні чинники розладу, пов'язаного з прив'язаністю.

Прикладом може слугувати ідеографічне дослідження підлітка. Він із повної родини, має достатній рівень навчальної успішності, високий рівень комунікабельності, займається спортом. На першому етапі відбувся відбір 12 осіб, до яких суб'єкт відчуває прив'язаність: це друзі та батьки. На другому етапі складена матриця, яка містить 12 регістрів (об'єкти прив'язаності) та 11 змінних (емоційні реакції). Досліджуваний повинен визначити, якої інтенсивності емоційні реакції він відчуває до кожного за 10-бальною шкалою.

Найбільш цінним показником $€$ кореляція емоційних реакцій. Особливість аналізу кореляційних зв'язків полягає у тому, що пряма й обернена кореляція вказують на формальну тотожність і змістовну нетотожність емоційних реакцій (їхній нерозривний суперечливий зв'язок). Однак у варіанті прямої кореляції йдеться про реакції одного полюсу парабіозу (в результаті зіткнення двох вогнищ збудження), а обернена кореляція може вказувати на антитетичні полюси нервово-психічної реакції. Іншими словами, це дозволяє формулювати припущення щодо цілісності структури емоційного феномену.
У досліджуваного найбільш потужно прямо зв'язані радість / подив $(0,87)$, огида / презирство $(0,84)$, інтерес / подив $(0,76)$, гнів / презирство $(0,75)$, сором / провина $(0,73)$, гнів / огида $(0,62)$, інтерес / радість $(0,6)$; обернений зв'язок діагностується між огидою / соромом $(-0,74)$, смутком / подивом $(-0,72)$, радістю / смутком $(-0,64)$. Наголосимо, що такі бінарні утворення слід розглядати саме як елементарні, а не диференційовані й потім осмолені асоціативним зв'язком. Отже, у найпростішому варіанті можемо зобразити феномен прив'язаності досліджуваного через вищезазначені бінарні утворення синонімічної й антонімічної природи. Втім, самі по собі такі бінарні формування виглядають «випадковими». На їхній основі неможливо збудувати єдину «емоційну теорію прив'язаності». Про прив'язаність говорять нервово-психічні реакції, які суб'єкт ідентифікує як «радість», «подив», «інтерес», але наше дослідження вказує на те, що за радістю може перебувати синонімічна реакція подиву й антонімічна - смутку. Власне, у цьому криється глибина емоції, її «спільність» із рештою реакцій.

Факторизація отриманих даних дозволяє встановити систему кореляційних зв'язків емоцій, їхню унікальність. Аналізу підлягають власні значення факторів (Eigenvalues) та факторні навантаження (Factor loading), факторний поворот робимо у Varimax normalized. Власні значення факторів говорять про те, що три фактори консолідують 78,5\% дисперсії: фактор 1 - 39,5\%, фактор 2 - 22,4\%, фактор 3 - 16,6\%. Таким чином, відмічаємо, що фактор 1 «пояснює» більше третини загальної дисперсії.

Насамперед звертаємо увагу на форму факторів - монополярний чи біполярний? Відповідь на це питання дозволяє зробити припущення щодо ступеня невротичності суб'єкта. Якщо фактор біполярний, тобто містить обернений зв'язок між елементами, фіксуємо цю суперечність як усвідомлення, бодай часткове, неоднозначного ставлення суб'єкта до об'єктів.

У нашому випадку перший - найпотужніший фактор - монополярний, причому із «негативними» показниками (табл. 1). Це може вказувати на брак внутрішнього конфлікту; водночас прив'язаність може трактуватися суб'єктом через його заперечення (гнів $(-0,918299)$, огида $(-0,786845)$, презирство $(-0,914349))$. Нагадаємо, що досліджуваний є підлітком i, вочевидь, у такий спосіб може транслюватися його сепарація.

Незначне усвідомлення розбіжностей в емоційному реагуванні фіксуємо у наступних двох факторах, які сумарно наближаються до першого. Суб'єкт певною мірою пов'язує синонімічні емоційні реакції інтересу $(0,839701)$, 
Факторні навантаження емоційних реакцій досліджуваного

\begin{tabular}{|l|c|c|c|}
\hline & Factor 1 & Factor 2 & Factor 3 \\
\hline Інтерес & 0,185063 & $\mathbf{0 , 8 3 9 7 0 1}$ & $-0,133355$ \\
\hline Радість & 0,200645 & $\mathbf{0 , 8 4 2 1 3 2}$ & 0,080463 \\
\hline Смуток & 0,112114 & $\mathbf{- 0 , 8 1 2 2 5 3}$ & $-0,174970$ \\
\hline Гнів & $\mathbf{- 0 , 9 1 8 2 9 9}$ & $-0,023204$ & 0,183770 \\
\hline Подив & 0,091571 & $\mathbf{0 , 9 3 5 7 5 9}$ & 0,195342 \\
\hline Огида & $\mathbf{- 0 , 7 8 6 8 4 5}$ & $-0,078263$ & $\mathbf{- 0 , 5 2 0 9 4 3}$ \\
\hline Презирство & $\mathbf{- 0 , 9 1 4 3 4 9}$ & $-0,175333$ & $-0,254751$ \\
\hline Збентеження & 0,066683 & $-0,468441$ & $\mathbf{- 0 , 5 2 0 6 6 3}$ \\
\hline Страх & 0,333590 & 0,287995 & $\mathbf{0 , 5 5 7 8 5 2}$ \\
\hline Сором & 0,313641 & $-0,121918$ & $\mathbf{0 , 9 0 3 5 2 2}$ \\
\hline Провина & $-0,084055$ & 0,099885 & $\mathbf{0 , 9 1 6 6 3 9}$ \\
\hline
\end{tabular}

радості $(0,842132)$ та подиву $(0,935759)$ з їхнім антагоністом - смутком $(-0,812253)$. Бесіда 3 досліджуваним дозволила з'ясувати, що під смутком розуміється не стільки печаль, скільки нудьга, «нецікавість». До слова, це вкотре засвідчує не тільки фактологічну помилку, але й суб'єктивність трактування емоції, що зумовлюється нервово-психічними нашаруваннями. У цьому разі смуток розуміється як неможливість радіти, цікавитися, дивуватися (антагоністична емоція).

Найбільш заплутаною $є$ спроба окреслити третю нервово-психічну реакцію, яка включає п'ять елементів. Тут немає класичного антагоністичного протиставлення емоцій: страху $(0,557852)$, сорому $(0,903522)$ та провині $(0,916639)$ протиставляються огида $(-0,520943)$ й збентеження $(-0,520663)$. Частково це теж може бути викликане суб'єктивним трактуванням емоцій, але може бути виявом специфіки амбівалентної емоції. Якщо окремі емоційні реакції можна пов'язати з певною причинно-наслідковою закономірністю в асоціативних тандемах страх / сором $(0,5)$, сором / провина $(0,73)$, то пояснити природу тандему огида / збентеження $(0,32)$ вкрай складно. Остання бінарна формація, дарма що має незначний кореляційний зв'язок, вочевидь пов'язана з нетиповою ситуацією виникнення (назагал тема для консультаційного пророблення).

Таким чином, перед нами достатньо неоднозначна плеяда емоційних реакцій, які пов'язані з особами, до яких суб' 'ккт відчуває прив'язаність. Рисунок 1 у тривимірному просторі дозволяє оцінити зв'язки між нервово-психічними реакціями. Їхня розгорнута інтерпретація показує, що суб'єкт, по-перше, може усвідомлювати прив'язаність як негативне явище, яке прагне його заперечити (фактор № 1); по-друге, протиставляє цікавість та нудьгу як основу прив'язаності (фактор № 2); по-третє, вочевидь, суб'єкт має специфічний досвід

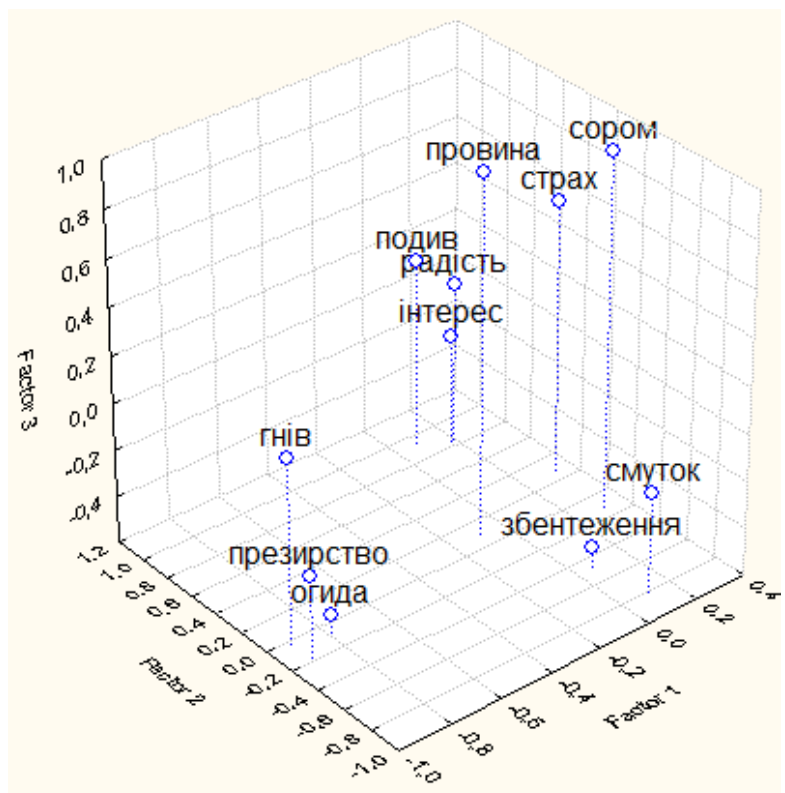

Рис. 1. Графічне представлення факторних навантажень (фактори 1, 2, 3)

фрустрації, який включає плеяду так званих негативних емоцій, неоднозначно пов'язаних між собою.

Зрозуміло, що така інтерпретація є первинною і вимагає посутнього уточнення з боку досліджуваного. Проте сама спроба аналізу у такій статистично-математичній редакції дозволяє окреслити плеяду найбільш актуальних нервово-психічних реакцій та виявити точки емоційної амбівалентності.

Висновки з проведеного дослідження. Результати ідеографічного дослідження підлітка, якого можна кваліфікувати як типового, показують, що прив'язаність у підлітковому віці не можна вважати структурно монополярним феноменом, що змістовно емоційний склад прив'язаності $є$ амбівалентним. Це дає підстави припустити, що прив'язаність як психологічний феномен не тільки закономірно 
ускладнюється, а набуває специфічної психодинаміки. Типовою особливістю прив'язаності у підлітковому віці можна вважати спробу суб'єкта її заперечити у плеяді так званих негативних емоційних реакцій (гнів, презирство, огида) і таким чином відчувати власну автономність та самодостатність. Водночас у конкретному випадку показано, що однозначної альтернативи такому негативізму досліджуваний не здатен запропонувати. Зокрема, інтерес, радість і подив виявляються ніби залежними від спроби захиститися від нудьги (смутку).

Висновки пілотажного ідеографічного дослідження дозволяють сформулювати окремі гіпотези щодо структурних та функціональних аспектів прив'язаності у підлітковому віці. Зокрема, націлюють простежити частоту вияву негативізму щодо осіб, до яких суб'єкт відчуває прив'язаність; з'ясувати змістовне наповнення амбівалентності (біполярності) емоційних реакцій; зафіксувати динаміку емоційного ставлення до осіб, до яких суб'єкт відчуває прив'язаність.

\section{ЛІТЕРАТУРА:}

1. Изард К.Э. Психология эмоций. Санкт-Петербург : Издательство «Питер», 1999. 464 с.

2. Леонтьев А.Н. Деятельность. Сознание. Личность. Москва : Политиздат, 1975. 304 с.
3. Мазяр О.В. Діагностика особистісної проблеми: емоційна сорера. Теорія і практика сучасної психології. 2019. № 4. Т. 1. С. 36-41.

4. МазярО.В. Особистісний дисонанс: системний аналіз : монограсрія. Житомир : Видавець О.О. Євенок, 2020. 332 c

5. Мазяр О.В. Психофізіологічний механізм фрормування невротичного розладу. Врачебное дело. 2017. № 7. С. 110-116.

6. Хорни К. Невроз и личностный рост. Борьба за самореализацию / [пер. Е.И. Замсрир ; терминологическая правка В. Данченко]. Санкт-Петербург : Восточно-Европейский институт психоанализа и БСК, 1997. 285 C.

7. Allen J.P., Porter M., McFarland C., McElhaney K.B., Marsh P. The relation of attachment security to adolescents' paternal and peer relationships, depression, and externalizing behavior. Child Development. 2007. № 78 (4). P. 1222-1239.

8. Prior V., Glaser D. Understanding attachment and attachment disorders: Theory, evidence and practice. London ; Philadelphia : Jessica Kingsley Publishers, 2006. $287 \mathrm{p}$

9. Shaw S.K., Dallos R. Attachment and adolescent depression: The impact of early attachment experiences. Attachment and Human Development. 2005. № 7 (4). P. 409-424.

10. Simpson J.A., Collins W.A., Tran S., Haydon K. Attachmentandtheexperienceandexpressionofemotions in romantic relationships: A developmental perspective. Journal of Personality and Social Psychology. 2007. № 92 (2). P. 355-367. 